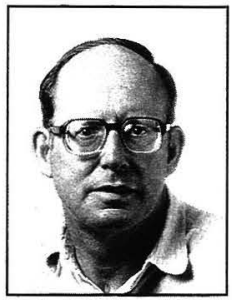

\title{
PSYCHOLOGICAL CONTRACTS IN DAIRY FARMING
}

\author{
Rupert Tipples and Eriko Gould \\ Applied Management and Computing \\ Division, Lincoln University.
}

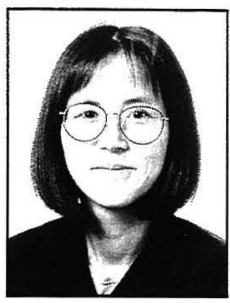

Improved employment relations are perceived as one way of further improving efficiency in the production of milk. To explore the existing state of employment relations in dairy farming and milk production a study of the psychological contracts existing between dairy farmer employers and dairy farm employees was initiated. Psychological contracts have been described as the invisible glue which binds employees to employers and vice versa over time. The term refers to the mutual expectations and perceived obligations existing between employers and employees beyond the normal components of a legal contract of employment. Using a critical incident approach to impute the content of psychological contracts, groups of employers and employees in major dairy farming areas were interviewed by paid student volunteers. This paper reports the initial findings of the study; suggests the implications of the results; and how the research may be developed.

\section{Keywords: Psychological contracts, dairy farming, critical incident method}

Employment relations issues have existed in dairy farming at least since the 1930s (Reid, 1977). The first Agricultural Wages Act, 1936, was directed specifically at dairy farming. At an industry based focus group, held in late 1997 to identify future land use and farming research needs, one of the major issues identified related to issues of employment in the dairy production sector. Specific concerns were "Labour mobility at peak season", "Sharemilking contracts with unreasonable cows/labour unit ratios", "Career opportunities and the image of dairying", "Career structures other than sharemilking", "Labour/staff management", and "Effects of large herd sizes on career paths".

The efficiency of labour use was also identified as a predominant information need of the industry in a review of the future of the Ruakura Dairy Farmer's conference (Mclean, Penno and Howse, 1997). Under the caption Labour Management, the availability, recruitment and retention of high quality farm staff, was identified as the largest single issue facing the dairy industry now and in the foreseeable future. To begin to explore this area, a project to study the content and types of psychological contracts existing in the dairy production industry was commissioned, for the psychological contract has been described as the glue which holds the employer and employee together in the employment relationship. It incorporates the beliefs, values, expectations and aspirations of the parties to the employment relationship (Herriot, 1992, 6).

The objectives of the project were to explore the content of the psychological contracts of those working in the dairy production sector, and then analyse the different importance of employers' and employees' perceptions of their mutual obligations, and their implications. The results would act as a vital input to developing appropriate employment strategies for the dairy production sector. Those employment strategies would also be informed by previous research (eg. Tipples, 1996).

\section{Methodology}

The content of New Zealand academics' psychological contracts (Tipples and Jones, 1998) had been explored through a critical incident approach following Herriot, Manning and Kidd (1997). This technique imputed the content of psychological contracts from "critical incidents" (as in Flanagan, 1954) and thus avoided attributional biases. Herriot et al. required their respondents:

"...to recall incidents at work where an employee or the organization went beyond or fell short of what might reasonably be expected of them in their treatment of the other party. It was reasoned that the nature of the obligation can be inferred from each incident of an expectation being violated or exceeded. It was assumed that the more frequently a particular category of obligation was cited, the more salient it was overall in the minds of the respondents, and thus the more prominent a component of the psychological contract for them."

(Herriot et al., 154)

They inferred twelve categories of organisational obligations and seven of employee obligations. Both groups identified these categories, but their relative salience differed. There were dangers in their holding different perceptions of the reciprocal factors balance. The implication of this was that an organisation should only expect their employees' commitment if they had fulfilled their side of the re- 
ciprocal exchange. Such an approach is an alternative to the standard questionnaire approach used by Rousseau, Robinson and colleagues in the U.S.A. (eg. Rousseau, 1990; Robinson and Morrison, 1995) and the basis of an earlier study (Tipples and Krivokapic-Skoko, 1997). However, the latter approach does not allow the subjects to tell "...their own stories" as it frames the subject matter through predetermined questions. Consequently major aspects may be omitted or overstated as Rousseau et al. did (Tipples and Jones, 1998). Herriot et al.' 's approach allows the content to be studied de novo and does not suffer from these problems. Consequently, a similar approach was chosen to study the content of psychological contracts in dairy farming.

To study the content of psychological contracts in dairy production it was planned to interview 50 dairy production employers and 50 dairy production employees. The critical incident approach investigated perceived critical incidents of good and bad employment behaviours at work (Table 1). To do this it was planned to have the interviews recorded and then transcribed. The transcripts were then subjected to a systematic analysis of content to identify the patterns of perceived obligations of dairy production employers and employees.

\section{Collection of data}

The primary author was to be out of New Zealand between April and the end of June 1998. The ideal time for collecting dairy production data is during that time of year as farmers are in the season between full production and calving. Consequently, it was decided to use paid farm management student interviewers. Student interviewers were believed to be ideal, especially when they came from dairy production areas. It was hoped they would be returning to their home areas during vacations in the selected period and would already know dairy farmers and their employees. Prospective interviewers were required to live in or come from a dairy production area and they had to be able to get to interviews easily. Following Herriot et al. (1997), interviewers were instructed to draw a convenience sample from their immediate acquaintance. As none had previous inter: viewing experience, training sessions were held prior to Easter 1998. They were asked to follow the procedures outlined in Appendix A.

Controlling a research procedure from the opposite side of the world with inexperienced assistants had some problems, as expected. Unexpected contingencies added to the problems. First, the semester length at Lincoln University was cut from 13 to 12 weeks in 1998, placing greater pressures on students than in former years. Of the ten interviewers selected, two pulled out before the research began. Another failed to complete any of the interviews planned. One interviewer only completed 7 interviews. One complete set of interviews was rejected as a result of a quality control check. The interviewer had ignored his instructions and paraphrased all the interviewees' responses rather than quoting exactly what was said. As a result of these problems only 57 useable interviews took place out of the hundred planned. From the data collected 476 incidents were identified.

Besides collecting critical incident data, interviewers were asked to collect a limited amount of classificatory data to help describe the interview sample. Some problems were encountered by interviewers in distinguishing the employment relationship, a contract of service between an employer and employee, and a contract for services between two independent parties (eg. the sharemilking relationship and the use of contract milkers). The issue was further complicated when a sharemilker or contract milker might also be an employer in their own right.

Interviewees were chiefly male; but three were female and three couples were interviewed. Just over half of those interviewed were in the North Island and just under half from

\section{Table 1. The content of psychological contracts of dairy farmers and dairy employees}

As a person working in the dairy production sector, please could you describe for me the employment incidents described below:

\begin{tabular}{l|l|l}
\hline Actor(s) & Dairy farmer/manager & Dairy farm employees \\
\hline Subject & Dairy farm employees & Dairy farmer/manager \\
\hline
\end{tabular}

Bad treatment 1. Where you think an employee or group of employees have been treated badly. By that I mean in a way that you regard as below how you would expect a dairy farmer/manager to treat you or your colleagues."

Good treatment

2. Where you think an employee or group of employees have been treated favourably. By that I mean in a way that you regard as beyond how you would expect a dairy farmer / manager to treat you or your colleagues."
3. Where you think a dairy farmer/manager was treated badly. By that I mean in a way that you regard as below how you would expect yourself or your colleagues to treat a dairy farmer/manager."

4. Where you think a dairy farmer/manager was treated favourably? By that I mean in a way that you regard as beyond how you would expect yourself or your colleagues to treat a dairy farmer /manager." 
Table 2. Categories of employment incidents and obligations imputed

\section{(a) Organisational obligations}

\begin{tabular}{|c|c|c|c|}
\hline Incidents Class: & Description of incident type & No & $\%$ \\
\hline 1. Training & Providing adequate induction and training. & 12 & 4.5 \\
\hline 2. Fairness & $\begin{array}{l}\text { Ensuring fairness of selection, appraisal, } \\
\text { promotionand redundancy procedures. }\end{array}$ & 0 & \\
\hline 3. Needs & Allowing time off to meet personal and family needs. & 12 & 4.5 \\
\hline 4. Consult & $\begin{array}{l}\text { Consulting and communicating with employees on } \\
\text { matters which affect them. }\end{array}$ & 13 & 4.9 \\
\hline 5. Discretion & $\begin{array}{l}\text { Minimal interference with employees in terms of } \\
\text { how they do their job. }\end{array}$ & 5 & 1.9 \\
\hline 6. Humanity & $\begin{array}{l}\text { To act in a personally and socially responsible and } \\
\text { supportive way towards employees. }\end{array}$ & 22 & 8.2 \\
\hline 7. Recognition & Recognition of or reward for special contribution or long service. & 33 & 12.3 \\
\hline 8. Environment & $\begin{array}{l}\text { Provision of a safe and congenial work environment; } \\
\text { managerial support etc. }\end{array}$ & 104 & 38.8 \\
\hline 9. Justice & $\begin{array}{l}\text { Fairness and consistency in the application of rules } \\
\text { and disciplinary procedures. }\end{array}$ & 3 & 1.1 \\
\hline 10. Pay & $\begin{array}{l}\text { Equitable with respect to market values and consistently } \\
\text { awarded across the organisation. }\end{array}$ & 32 & 11.9 \\
\hline 11. Benefits & Fairness and consistency in the administration of the benefit system. & 25 & 9.3 \\
\hline 12. Security & $\begin{array}{l}\text { Organisations trying hard to provide what job security they can; } \\
\text { jobs preserved in redundancy, illness or accident as far as possible. }\end{array}$ & 7 & 2.6 \\
\hline
\end{tabular}

TOTAL

268

(b) Employee obligations

\begin{tabular}{|c|c|c|c|}
\hline Incidents Class: & Description of incident type & No & $\%$ \\
\hline 13. Hours & To work the hours you are contracted to work. & 44 & 21.2 \\
\hline 14. Work & To do a good job in terms of quality and quantity. & 29 & 13.9 \\
\hline 15. Honesty & To deal honestly with the clients and with the organisation. & 24 & 11.5 \\
\hline 16. Loyalty & $\begin{array}{l}\text { Staying with the organisation, guarding its reputation, and } \\
\text { putting its interests first. }\end{array}$ & 56 & 26.9 \\
\hline 17. Property & Treating the organisation's property in a careful way. & 41 & 19.7 \\
\hline 18. Self-presentation & Dressing and behaving correctly with customers and colleagues. & 11 & 5.3 \\
\hline 19. Flexibility & $\begin{array}{l}\text { Being willing to go beyond one's own job description, } \\
\text { especially in emergency. }\end{array}$ & 3 & 1.4 \\
\hline
\end{tabular}

TOTAL 
the South Island. Most were from rural areas, but 5 were living on an urban fringe. Nearly half ( 49 percent) were farm owners or operators, or partners, and 7 (12 percent) were sharemilkers. Thirty-eight percent were employees of which 11 percent were managers or herd managers, and just over a quarter (26.4 percent) called themselves farm workers or employees, or students or cadets. Only two interviewees were involved in businesses with no full-time employees, but 22 ( 45 percent) of businesses had only one full-time worker. At the other end of the employment scale a quarter of interviewees were involved in businesses with 3-7 full-time staff. The wide variation in the size of the employment unit corresponded to herd sizes ranging from $140-1,000$ cows. The median herd size was 350 cows and the modal size 500 ( 5 herds).

\section{Results}

Incidents were categorised using the categories identified by Manning (1992). Manning's framework seemed to cope adequately with all the incidents cited. Where difficulties in categorisation were encountered, reference was made to Manning's original thesis. No additional categories were found to be necessary. The final categorisation of critical employment incidents using Manning's framework is given in Tables 2(a) and 2(b). The incidents were divided into two groups: those imputing organisational obligations (268 incidents) and those imputing employee obligations (208 incidents). Of the former 162 were cited by the employer group of interviewees and 106 by the employee group. Of the latter, 145 were cited by the employer group of interviewees and 63 by the employee group. In terms of the obligations imputed to dairy employers (Table 1, forms 1 and 2; displayed in Table 2a), the most salient, those most frequently cited, were those relating to the work Environment, which were 38.8 percent of incidents. The second most salient group of incidents were those relating to Recognition (12.3 percent), followed by those relating to Pay (11.9 percent). Selected quotes from interviews are given below to give a flavour of the material collected. The number following the quote is the interview code number.

\section{Form 1. Poor treatment by employer:}

\section{- Category 8: Environment}

"Employee being expected to get the cows in morning and afternoon, seven days a week, being given off only 2 hours a week and one weekend a month" (HR8)

"No contract, boss kept changing things" (HR9)

"Seasonal pressures lead to aggression in the workplace, uneven financial inflow can bring about stress" (HC8)

\section{- Category 10: Pay}

"Boss taking advantage of employee having no prior knowledge in the industry and underpaying him and expecting him to work long days" (HR9)

"Withholding pay, or pay day postponed" (HC8)

"Worker left, boss wouldn't pay wages still owing. Worker threatened legal action. 2 days prior to Employment Tribunal the money was paid through" (WBI)

\section{Form 2. Good treatment by employer:}

\section{- Category 7: Recognition}

"At end of contract given 10 heifers as bonus" (HC5)

"Taking employees out to tea" (HC5)

"Bonuses in the way of calves and cash at the end of the season" (WSI)

\section{- Category 8: Environment}

"Buying you extra wet weather gear" (HR9)

"Employer tries to find the skills and abilities of the employee and if they enjoy working more with stock or tractor work (working with machinery) then allows them to do more of that work. Tries to bring it out in them, so to ensure that they enjoy what they're doing" ( $\mathrm{HClO}$ )

\section{- Category 10: Pay}

"Pay workers above the award rate" (WS3)

"Rewarding work done generously in the pay packet" (HR3)

"Pay above district average and overtime above normal hours at a flat rate" ( $\mathrm{JO4}$ )

Of employee obligations (Table 1, forms 3 and 4; displayed in Table $2 b$ ), the most frequently cited were those relating to Loyalty (26.9 percent), then to Hours (21.1 percent), thirdly to Property (19.7 percent).

\section{Form 3. Poor treatment by employees:}

\section{- Category 13: Hours}

"When an employee was left to their own devices and took advantage of this, by not putting in the hours required in between milkings doing on farm work" (HRI)

"Employees coming home late, getting drunk and not turning up to milk in the morning" (HR2)

"Employee came to work late every day for months till he was fired, then in his last 2 weeks while he was given notice he didn't come at all" (JO7)

\section{- Category 16: Loyalty}

"Staff leaving at critical times with short notice" (JO3)

"In another situation an employee leaving one week into calving with one day's notice" (JO4)

"Employee asked boss if he could purchase a working dog for use on the farm. Boss said no but the worker went ahead and got one anyway" (JO9)

\section{- Category 17: Property}

"When an employee starts knocking the cows around...Not taking care of the manager's machinery which affects cash flow" (HR3)

"One of the bedrooms in the house supplied set up to grow dope. Owner had been paying the power bill" (HR8)

"Cows broke fence but worker wouldn't fix it because didn't feel he should because he didn't own the cows and it was the employer's cows who had broken it" ( $\mathrm{HClO})$ 


\section{(a) Imputed obligations in dairy production compared to academe.}

Tipples: NZ Academics 1997

\begin{tabular}{lllllllll} 
Priority & Managers & $\%$ & Employees & $\%$ & Managers & $\%$ & Employees & $\%$ \\
\hline 1 & Environment & $(24)$ & Environment & $(18)$ & Environment & $(40)$ & Environment & $(37)$ \\
2 & Recognition & $(20)$ & Recognition & $(15)$ & Recognition & $(15)$ & Pay & $(15)$ \\
3 & Consult & $(15)$ & Fairness & $(13)$ & Pay & $(10)$ & Benefits & $(12)$ \\
4 & Faimess & $(9)$ & Security & $(13)$ & Humanity & $(7)$ & Humanity & $(9)$ \\
& Security & $(9)$ & & & Benefits & $(7)$ & & \\
\hline
\end{tabular}

(b) Imputed obligations of dairy production employees compared to academic employees.

Tipples: NZ Academics 1997

Tipples: NZ Dairy Production 1998

\begin{tabular}{lllllllll} 
Priority & Managers & $\%$ & Employees & $\%$ & Managers & $\%$ & Employees & $\%$ \\
\hline 1 & Hours & $(32)$ & Work & $(33)$ & Property & $(27)$ & Hours & $(35)$ \\
2 & Work & $(30)$ & Hours & $(25)$ & Loyalty & $(24)$ & Loyalty & $(33)$ \\
3 & Loyalty & $(26)$ & Loyalty & $(23)$ & Hours & $(15)$ & Work & $(13)$ \\
\hline
\end{tabular}

\section{Form 4. Good treatment by employees:}

\section{- Category 13: Hours}

"An employee offered to continue to milk over Christmas to allow the owner to have a holiday without being asked to" (HRI)

"Employee completed some tractor work after tea in his own time to get the task out of the way" (JO3)

"Putting in work time on weekend off" (HR7)

- Category 16 Loyalty

"Dairy farmer had been sick and worker has been given time off but comes back until farmer well enough, because things had to be done" ( $\mathrm{HC} 3$ )

"Mother died and when came back all silage was done" (HC8)

"Employee puts farm and job ahead of anything else" (JO7)

"Farm vehicle broke down and employee was willing to use his own vehicle" (JO7)

\section{- Category 17 Property}

"To help the employer's formal budget the employee improvised by borrowing equipment and putting off purchases, even though the expenditure had been approved" (HR1)

"Employee mowing the manager's lawns and weeding his garden without being asked to" (HR5)

"Alistair had a sick cow. He was ready to put it down but the worker said he would give it a go, so he and his wife spent another 5-6 days feeding it and lifting it up to try and get it back on its feet - after Alistair was ready to put it out of its misery" (WB5)

\section{Comparison with previous research}

For all of the groups in the comparison of the content of psychological contracts in New Zealand academe and dairy production (Table 3(a)) the work Environment was the most important component of organisations' psychological contracts with their employees. However, twice the proportion of dairy production critical incidents concerned the work environment. In terms of obligations of the organisation to the staff recognition was of second importance to academic staff and dairy managers (15-20 percent of incidents), while Pay was of second most importance to dairy production employees. This result is hardly surprising in the light of the reputation of the dairy sector for low wage levels. Of third and fourth importance were the proportions on incidents relating to Consultation, Fairness and Security for academe, and for Pay, Benefits and Humanity for dairy production

Herriot et al.(1997) concluded that both employer/manager and employee groups cite the most frequently as employee obligations the traditional components of doing a good job in terms of quality and quantity, and time worked. For University staff, the third major component was loyalty; in the UK honesty was third. In dairy production employers/managers cited most frequently issues relating to Property, then Loyalty and Hours, while employees put Hours first, then Loyalty and Work. 
In few cases were the components of the psychological contracts imputed fully balanced. The reciprocal nature of the contract was perceived differently by employer/manager groups and employee groups, but there was no consistency in the differences (Table 4). If one considers dairy production employers' views, employer good treatments of employees outweighed bad treatments for the categories for Needs, Consult, Discretion, Humanity, Recognition and Security. However, bad treatments outweighed good treatments for Environment, Justice, Pay and Benefits - including two of the most cited incidents - Environment and Pay. For employee treatments of the employer, the categories for Hours and Property were relatively balanced. Employee bad treatments of the employer exceeded good treatments for the categories Work Honesty and Self Presentation, but employee good treatments exceeded bad for the categories Loyalty and Flexibility.

\section{Discussion}

As Herriot et al.'s categorisation of the content of psychological contracts seems to cover all the cases identified in the dairy production industry, the major issue is not the content of the psychological contract but the reciprocal balance between the parties to the employment relationship. What is regarded as a fair-exchange deal? There was no significant difference (chi-square $=.65737,10$ d.f.) in the views of employers and employees of the content of employer obligations. Both parties regarded the work Environment as the critical issue, followed by issues of Recognition and Pay. However, for employee obligations, there were significant differences (chi-square $=.000651,6$ d.f.). The employers interviewed emphasised issues of Property (26.9 percent of incidents) compared to only 3.2 percent for employees. Employees emphasised Hours (34.9 percent of incidents) and Loyalty (33.3 percent) compared with employers 15.2 percent and 24.1 percent respectively. Herriot et al. suggest from their English research that employees tend to emphasise 'fundamental hygiene factors" of the employment relationship whereas employers tended to focus on more relational factors. However, the views of the two groups in New Zealand were not distinguishable in terms of employer obligations. The employer group viewed property issues as a major obligation of employees, perhaps because employees have the chance to make or break the financial success of the business by the way in which they look after the farmer's farm, stock and machinery. Work, Honesty, Self-presentation and Flexibility were indistinguishable between the employer and employee groups.

\section{Conclusions}

Herriot, Manning and Kidd's critical incident approach does provide a viable way to assess the content of psychological contracts de novo. In terms of the obligations which face employees, perceptions of the content of psychological

Table 4. Incidents grouped by form of incident

\section{(a) Dairy production employer treatments}

\begin{tabular}{lrrr}
\hline Incident class: & Employer bad treatment $\%$ & Employer good treatment $\%$ & Number of incidents \\
\hline 1. Training & 50 & 50 & 12 \\
2. Fairness & 0 & 0 & 0 \\
3. Needs & 0 & 100 & 12 \\
4. Consult & 38 & 62 & 13 \\
5. Discretion & 40 & 60 & 5 \\
6. Humanity & 36 & 64 & 22 \\
7. Recognition & 3 & 97 & 33 \\
8. Environment & 66 & 34 & 104 \\
9. Justice & 67 & 33 & 3 \\
10. Pay & 69 & 31 & 32 \\
11. Benefits & 100 & 0 & 7 \\
12. Security & 9 & 91 & 22 \\
\hline
\end{tabular}

(b) Dairy production employee treatments

\begin{tabular}{|c|c|c|c|c|}
\hline Incident class: & Employee bad treatment & $\%$ & Employee good treatment $\%$ & Number of incidents \\
\hline 13. Hours & & 50 & 50 & 44 \\
\hline 14. Work & & 62 & 38 & 29 \\
\hline 15. Honesty & & 100 & 0 & 24 \\
\hline 16. Loyalty & & 39 & 61 & 56 \\
\hline 17. Property & & 51 & 49 & 41 \\
\hline 18. Self presentation & & 73 & 27 & 11 \\
\hline 19. Flexibility & & 0 & 100 & 3 \\
\hline
\end{tabular}


contracts appear to be concerned partly with the traditional issue of the time applied to work, Hours, and Loyalty to the employer, from the employee's perspective. From the employer's perspective the dominant factor was Property followed by Loyalty. Obligations of the employer centred around providing a suitable work Environment, Recognition and Pay in both employers' and employees' views.

Employer/managers and Employees had some different views on the most salient features of psychological contracts. These differences have to be addressed in establishing matching psychological contracts.

\section{Implications}

Herriot, Manning and Kidd's "critical incident" approach could be used to investigate de novo the content of psychological contracts for other groups of workers. It has now been applied to quite different groups - dairy staff and academics, albeit with quite limited samples. This approach can then provide the guidance on the critical issues to take into account when attempting to advise on factors critical to the success of the employment relationship.

To establish sound employment relationships mutually matching psychological contracts have been advocated (Tipples, 1996). From the perspective of the employers' obligations, the major focus must clearly be on factors affecting the work Environment. Both employers and employees have to be clear that this is the most significant factor. That means that both parties have to be clear what working in the dairy industry and for a particular business means in practice. That involves substantial discussion, thinking and understanding of the other party's views. Similarly there needs to be the same clarity about pay and recognition for significant performance.

View's of the employees' obligations differed. Consequently there is clearly a need to address the issue of the 'owner's' property. That means that there should be no hidden surprises about property issues. Employers have to spell out property rules clearly and ensure that employees are adequately trained, not only for the purposes of the Health and Safety in Employment Act 1992, but also to avoid 'property' problems. For example, large irrigators can be very expensive, difficult to handle and easy to damage. On light land they are a vital piece of equipment and their loss could have serious implications in terms of reduced milk output. Similarly, issues of employee loyalty, work quantity and quality have to be openly addressed. Again more discussion, thinking and understanding of issues is likely to lead to better matching psychological contracts, which should in turn lead to longer lasting employment relationships.

The employment relationship is a reciprocal relationship. Those who breech their obligations to the other party cannot expect them to keep their side of any previously agreed bargain. Herriot et al.'s focus on the transactional nature of the relationship should not be ignored. Failure to look after staff will lead to their failure to look after the employer/manager.

\section{Future research}

The research reported in this paper has been based on very small samples. Further validation of the research in the dairy production sector would be desirable, especially at a scale permitting evaluation of the effects of scale of enterprise and the influence of respondent age. So far investigation of the content of psychological contracts of only two occupational groups in New Zealand has taken place. The original research reported in Herriot et al.,1997, covered all sorts of occupations in the U. K. Therefore it would be useful to carry out further studies in other occupations. However, one question which has not been addressed so far, but which seems very appropriate for New Zealand, is to explore the content of psychological contracts for different ethnic groups. Do Maori and Pacific island expectations and work values differ significantly from the European bulk of the community?

\section{References}

Flanagan, J.C. (1954) The critical incident technique, Psychological Bulletin, 51, 327-358.

Herriot, Peter (1992) The Career Management Challenge. London: Sage Books Ltd.

Herriot, Peter; Manning, W.E.G.; Kidd, Jennifer M. (1997) The content of the psychological contract, British Joumal of Management, 8, 151-162.

Manning, W.E.G. (1992) The content of the psychological contract between employees and organisations in Great Britain in the early 1990s. Ph.D thesis, London University.

Robinson, Sandra L. and Morrison, Elizabeth W. (1995) Psychological contracts and OCB: The effect of unfulfilled obligations on civic virtue behavior, Journal of Organizational Behavior, Vol. 16, no. 3, 289-298.

Rousseau, D.M. (1990) New hire perceptions of their own and their employer's obligations: a study of psychological contracts, Journal of Organisational Behavior, 11, 5, 389-400.

Tipples, Rupert (1996) Contracting: The Key to Employment Relations, International Employment Relations Review, 2, 2, December, 19-41.

Tipples, Rupert and Krivokapic-Skoko, Branka (1996) New Zealand academics and performance management - Changing academic careers, legal and psychological contracts at Lincoln University since 1990. 4th Conference, International Employment Relations Association, Southern Cross University, N.S.W. 10-12 July.

Tipples, Rupert and Krivokapic-Skoko, Branka (1997) New Zealand Academics and Performance Management, International Journal of Employment Studies, 5(2), 103-116.

Tipples, Rupert and Jones, Paul (1998) Extra-contractual relations: the substance of academics' psy- 
chological contracts in New Zealand, in Harbridge, Raymond: Gadd, Claire and Crawford, Aaron (eds.) Current Research in Industrial Relations, Proceedings of the 12th AIRRANZ Conference, Victoria University of Wellington, 3-5 February 1998.

\section{Appendix A:}

\section{Interview procedure for dairy farm employment interviews}

\section{Strategies for selecting dairy personnel}

Think of as many dairy farming personnel (farmers/ managers/workers) as you can/know:

- List them, and randomly select until you have the right number (flip a coin or use random numbers).

- Use you contacts/networks/relatives/previous experiences to develop your initial list.

- Try and select different sizes of dairy farm - small medium/large herds.

N.B. You are looking for dairy employers (farmers and managers) and dairy employees/workers.

2. Before the interview: Check the battery power level using the indicator lights on the tape recorder, check the tape, and record the number of the interview.

3. Begin the interview: Give the subject the Consent letter. Read/explain the project and ask them to sign the Tear-off slip, and give it back to you.

4. Complete the Background questions (Appendix B) by asking questions, observation, or from your records.

5. Ask the subject about their recollections of employment incidents. Use the lead-in statement provided and all of the four questions in turn. N.B. Questions 1 and 2 concern actions of the employer on employees; and Questions 3 and 4 concern the actions of employees on the employer. It is best to stick to the wording provided.

6. Record as many incidents as the subject volunteers. You may need to probe gently. Do not be put off by an instant claim of not knowing any incidents. Talk around the questions to get your subject thinking. Try not to lead them.

7. After the interview: Go back over the tape and write down in summary form the key details of each incident, indicating clearly between incidents by numbering or a dividing line on the Report form provided.

8. When you have concluded as many interviews as you can (10 initially: 5 employers and 5 employees, then ask Liz Burtt if you can do more), please return the tear-off consent slips, tape recorder, tapes - both used and unused, any remaining batteries, numbered background questions, and all transcript report forms.

\section{Authors}

Rupert Tipples is a Senior Lecturer in Employment Relations, and Eriko Gould is a Research Assistant at the Applied Management and Computing Division, Lincon University,

PO Box 84, Canterbury.

Email: tipplesr@lincoln.ac.nz 